\title{
Synthesis and Characterization of Nanocrystalline YSZ Powder by Smoldering Combustion Synthesis
}

\author{
Ingeborg Kaus, Paul Inge Dahl, Johann Mastin, Tor Grande, and Mari-Ann Einarsrud \\ Department of Materials Science and Engineering, Faculty of Natural Sciences and Technology, \\ Norwegian University of Science and Technology (NTNU), 7491 Trondheim, Norway
}

Received 22 August 2005; Revised 5 May 2006; Accepted 9 May 2006

Recommended for Publication by Michael Z. Hu

\begin{abstract}
Nanocrystalline yttria-stabilized zirconia (YSZ) powders with $8 \mathrm{~mol} \% \mathrm{Y}_{2} \mathrm{O}_{3}$ have been produced using smoldering combustion synthesis with glycine as fuel and nitrate as oxidizer. The YSZ powders prepared by using different glycine to nitrate ratios $(0.20-$ 1.0) have been characterized by X-ray diffraction (crystallite size), thermogravimetry, infrared spectroscopy, surface area analysis, transmission electron microscopy, and dilatometry to determine the parameters giving the powder the best properties when it comes to densification properties. The influence of calcination temperature on crystallite size, surface area, and carbonate species remaining from the smoldering combustion reaction has been studied especially for the $\mathrm{G} / \mathrm{N}$ ratio of 0.23 to reveal the optimal synthesis conditions. A G/N ratio of 0.23 and calcination in the range $650-900^{\circ} \mathrm{C}$ in oxygen flow gave high quality powder with a crystallite size less than $10 \mathrm{~nm}$. Densities of sintered bodies exhibit an increase for calcination temperatures above $600^{\circ} \mathrm{C}$, where most of the residual carbonate species has been removed.
\end{abstract}

Copyright (c) 2006 Ingeborg Kaus et al. This is an open access article distributed under the Creative Commons Attribution License, which permits unrestricted use, distribution, and reproduction in any medium, provided the original work is properly cited.

\section{INTRODUCTION}

Yttria stabilized zirconia (YSZ), with its high ionic conductivity and low electronic conductivity, is generally the material of choice as an electrolyte in, for example, solid oxide fuel cells [1], and has been so for several decades. A high quality starting powder is a prerequisite to obtain a highperformance zirconia material. There are various methods for synthesis of high-quality oxide powders; among them are precipitation techniques $[2,3]$, combustion techniques [4$6]$, sol-gel techniques $[7,8]$, and hydrothermal techniques [9]. All these different techniques are based on a solutiontype chemistry, where precursors of the various cations are dissolved in a solvent, commonly water, and then mixed in appropriate proportions.

Nanocrystalline materials have received much attention lately because their properties often are different from those of the corresponding microstructured materials. The variation in properties is due to the large number of grain boundaries compared to a specimen with larger grains. Nanosized powders are essential as a starting point for making nanocrystalline ceramics.

The current investigation focuses on a novel smoldering combustion-type synthesis, using a solution of nitrates, with glycine as the complexing agent and fuel for the reaction. For simplicity, if only the reaction to produce $\mathrm{ZrO}_{2}$ is taken into consideration, the stoichiometric combustion reaction occurs according to the following reaction equation assuming the gaseous products to be $\mathrm{H}_{2} \mathrm{O}, \mathrm{CO}_{2}$, and $\mathrm{N}_{2}$ :

$$
\begin{gathered}
9 \mathrm{ZrO}\left(\mathrm{NO}_{3}\right)_{2} \cdot 6 \mathrm{H}_{2} \mathrm{O}(\mathrm{aq})+10 \mathrm{NH}_{2} \mathrm{CH}_{2} \mathrm{COOH}(\mathrm{aq}) \\
\Rightarrow 9 \mathrm{ZrO}_{2}(\mathrm{~s})+14 \mathrm{~N}_{2}(\mathrm{~g})+20 \mathrm{CO}_{2}(\mathrm{~g})+79 \mathrm{H}_{2} \mathrm{O}(\mathrm{g})
\end{gathered}
$$

yielding a $\mathrm{G} / \mathrm{N}$ ratio of 0.55 . To our knowledge, this method has been reported only a few times for the preparation of YSZ. The paper by Mimani and Patil [10] does, however, only report the powder production, with a very brief description of the method and characterization of the powder, whereas this contribution aims at giving a detailed description of the synthesis process and a thorough evaluation of the resulting powders.

Glycine is an interesting complexing agent, as it can complex a cation at both the carboxylic acid end and the amino group end as illustrated in Figure 1. Which site is preferred depends on the size and charge of the cation and the $\mathrm{pH}$. The most important issue regarding the glycine: cation $(\mathrm{G} / \mathrm{C})$ ratio is that there has to be sufficient glycine in the solution to retain the cations completely complexed as the solution is 
<smiles>NCC([O-])=[OH+]</smiles><smiles>[14C]NCC(=O)O</smiles><smiles>[O+][O+][O-]</smiles>

FIgURE 1: Zwitterionic glycine molecule complexing $\mathrm{ZrO}^{2+}$.

being evaporated. This is especially important in the case of $\mathrm{ZrO}_{2}$, since the solubility of the zirconyl ion in water is very low [11].

In general, a combustion reaction ignites spontaneously, with glycine as the fuel and the nitrates from the metal nitrate precursor as the oxidizer. The temperature of the ignition reaction, however, depends on the fuel-to-oxidizer ratio (glycine:nitrate $(\mathrm{G} / \mathrm{N})$ ratio) and which metal cations are introduced into the solution [12]. Mukasyan et al. [13] have defined three combustion modes depending on the $\mathrm{G} / \mathrm{N}$ ratio for $\mathrm{La}_{0.8} \mathrm{Sr}_{0.2} \mathrm{CrO}_{3}$ : smoldering combustion synthesis (SCS): $\mathrm{G} / \mathrm{N}<0.39, \mathrm{~T}<600^{\circ} \mathrm{C}$; volume combustion synthesis (VCS): $0.39<\mathrm{G} / \mathrm{N}<0.66,1150^{\circ} \mathrm{C}<\mathrm{T}<1350^{\circ} \mathrm{C}$; self-propagating high-temperature synthesis (SHS): $0.66<\mathrm{G} / \mathrm{N}<0.88,800^{\circ} \mathrm{C}$ $<\mathrm{T}<1100^{\circ} \mathrm{C}$. They observed that powders produced in the SCS range need to be calcined, whereas powders produced at higher $\mathrm{G} / \mathrm{N}$ ratios may be sintered as-synthesized. Chick et al. [12] have also measured the temperature of the combustion reaction producing $\mathrm{Sr}$ substituted $\mathrm{LaCrO}_{3}$ and have found that the temperature reaches a peak at an intermediate $\mathrm{G} / \mathrm{N}$ ratio of 0.55 consistent with the report by Mukasyan et al. [13]. Mokkelbost et al. [14] observed an increase in ignition temperature with increasing $\mathrm{G} / \mathrm{N}$ ratios at $\mathrm{G} / \mathrm{N}$ ratios below 0.55 when producing ceria but did not observe a change above 0.55 . For systems with no catalytic active cations, the combustion might be in the SCS mode for a wider range of $\mathrm{G} / \mathrm{N}$ ratios.

The reaction temperature affects the degree of crystallization in the final powder, and if the combustion temperature does not reach the crystallization temperature, an amorphous semi-decomposed precursor powder will result. When a high combustion temperature is reached, particle growth is limited by the short reaction time, and the turbulence caused by the gas evolution during the reaction limits the degree of agglomeration.

In the following, this novel synthesis method for nanocrystalline YSZ powders is described in detail, and the resulting powders are characterized. The parameters for the synthesis of the most promising powder for densification properties are identified.

\section{EXPERIMENTAL}

\subsection{Powder synthesis}

Nanocrystalline powders of YSZ with $8 \mathrm{~mol} \% \quad \mathrm{Y}_{2} \mathrm{O}_{3}$ were prepared using a glycine/nitrate smoldering combustion method. Individual solutions of zirconyl nitrate hydrate $\left(\mathrm{ZrO}\left(\mathrm{NO}_{3}\right)_{2} \cdot 6 \mathrm{H}_{2} \mathrm{O}\right.$, Acros Organics, > 99.5\%) and yttrium nitrate $\left(\mathrm{Y}\left(\mathrm{NO}_{3}\right)_{3} \cdot 6 \mathrm{H}_{2} \mathrm{O}\right.$, Merck, > 99\%) were made by dissolving the nitrate salts in distilled deionized water. In order to remove precipitates, the $\mathrm{ZrO}\left(\mathrm{NO}_{3}\right)_{2}$ solution was filtered through porcelain filter crucibles (Haldenwanger, 84-2P2). Both solutions were standardized by thermogravimetric analysis. The solutions were mixed in the appropriate proportions and glycine (Merck, > 99.7\%) was added. G/C ratios from 0.43 to 2.17 were used, and no additional nitrate was added. The variation in $\mathrm{G} / \mathrm{C}$ ratio hence resulted in a variation in $\mathrm{G} / \mathrm{N}$ ratio from 0.20 to 1.0. The resulting solution was stirred overnight and evaporated in small portions $(\sim 100 \mathrm{ml}$, producing $3-5 \mathrm{~g}$ powder) in a tall beaker (approx. $60-70 \mathrm{~cm}$ tall) on a hotplate at $200^{\circ} \mathrm{C}$, until self-ignition occurred. A smoldering combustion reaction, which is much less violent than a volume combustion reaction, was observed for all G/N-ratios, and the powder was usually well contained within the beaker. Care should be taken, however, to ensure that the batches are sufficiently small to avoid an unmanageable reaction, both for safety reasons and also to ensure a homogeneous reaction. The resulting fine powders were precalcined at $400^{\circ} \mathrm{C}$ for $12 \mathrm{~h}$. The pre-calcined powders were then ball milled in ethanol for $24 \mathrm{~h}$ using YSZ milling media, dried using a rotavapor, and calcined at temperatures from $400^{\circ} \mathrm{C}$ to $1000^{\circ} \mathrm{C}$ for $12 \mathrm{~h}$ using heating/cooling rates of $200^{\circ} \mathrm{C} / \mathrm{h}$. To effectively remove residual nitrate and organic materials, calcination was performed with oxygen flow through the powder. The quartz tube furnace used for this purpose was limited to $600^{\circ} \mathrm{C}$. Therefore a box furnace (Entech, MF 1/12) was used for calcination at higher temperatures. This furnace operated in air so for high-temperature calcination the powders were precalcined at $600^{\circ} \mathrm{C}$ in oxygen flow.

\subsection{Characterization}

The prepared powders were analyzed by X-ray diffraction (XRD) (Siemens D5005) with $\mathrm{Cu} \mathrm{K}_{\alpha}$ radiation through a primary monochromator. From these data the structure of the powders was confirmed. The cell parameter and theoretical density were calculated by the Rietveld method. The computer program "Profile" [15] was used to fit the raw data peaks to a Pearson VII mathematical model. The data from the fittings were used to calculate crystallite size, using the program "Crysize" [16]. A standard of $\mathrm{LaB}_{6}$ (NIST standard no. 660A [17]) fitted to a Pearson VII model was used as a reference to correct for instrumental broadening. 
Nitrogen adsorption on the powders was measured (Micromeritics ASAP 2000) using the 5-point BET equation to give the specific surface area. Degassing was performed at $250^{\circ} \mathrm{C}$ for $24 \mathrm{~h}$, and typical measuring pressures were 8,43 , 88,168 , and $245 \mathrm{~mm} \mathrm{Hg}$. The particle size was calculated from these results assuming spherical particles. The powders were also deposited on holey carbon-coated copper grids and studied in a transmission electron microscope (Philips CM30) operated at an accelerating voltage of $300 \mathrm{kV}$. Infrared spectra were recorded on $\mathrm{KBr}$ pellets containing $1 \mathrm{wt} \%$ YSZ powder on a Bruker IFS $66 \mathrm{v}$ spectrophotometer.

Weight loss upon heating was monitored using thermogravimetry (TG) (NETZSCH STA 449 C Jupiter). The powders were heated to $1000^{\circ} \mathrm{C}$ in air, with a heating rate of $2 \mathrm{~K} / \mathrm{min}$.

The sintering behavior was studied using a dilatometer (NETZSCH DIL 402 C). Pellets were uniaxially pressed at $\sim 64 \mathrm{MPa}$ and further densified in a cold isostatic press at $200 \mathrm{MPa}$ to green densities in the range of 35 to $38 \%$ of theoretical. The pellets were heated to $1450^{\circ} \mathrm{C}$ in air, with a $3 \mathrm{~K} / \mathrm{min}$ heating rate. Density of the green pellets was measured geometrically, whereas density of the sintered pellets was measured using the Archimedes principle. Isopropanol was used as the liquid medium, and the theoretical density was calculated from the XRD data.

\section{RESULTS}

The synthesis reaction with $\mathrm{G} / \mathrm{N}=0.23$ produced a fluffy white powder, whereas for the synthesis with a lower $\mathrm{G} / \mathrm{N}$ ratio, the smoldering combustion reaction gave a semidecomposed precursor. The smoldering combustion reaction was less complete for $\mathrm{G} / \mathrm{N}$ ratios above 0.23 , and the resulting powder was brown and compact. The temperature of the reaction did not appear to reach above $600^{\circ} \mathrm{C}$ for any $\mathrm{G} / \mathrm{N}$, and the reaction hence stayed in the SCS regime for all $\mathrm{G} / \mathrm{N}$ ratios investigated. $\mathrm{NO}_{2}$ evolved during the smoldering combustion.

The XRD data show that the average cubic lattice parameter is $5.139 \AA$, yielding a theoretical density of $5.96 \mathrm{~g} / \mathrm{cm}^{2}$, which is consistent with the data from Feighery and Irvine [18].

The X-ray diffractograms of powders with different G/N ratios, calcined at $400^{\circ} \mathrm{C}$, are shown in Figure 2(a). The insert shows the crystallite size as a function of $\mathrm{G} / \mathrm{N}$ ratio. The crystallite size shows a maximum at $\mathrm{G} / \mathrm{N}=0.30$. It should be noted that the detection limit for crystallite size is approximately $2 \mathrm{~nm}$, and calculated crystallite sizes below this limit have large relative errors. Figure 2(b) shows the X-ray diffractogram development with increasing a calcination temperature of the powder with $\mathrm{G} / \mathrm{N}=0.23$, and the variation in crystallite size with calcination temperature is shown in Figure 3. The corresponding data for powder with $\mathrm{G} / \mathrm{N}=1.0$ are also included in Figure 3. The crystallite size increases with increasing the calcination temperature, slowly at low temperatures, and more rapidly at higher temperatures. The two different $\mathrm{G} / \mathrm{N}$ ratios yield powders with comparable crystallite sizes at low calcination temperatures.

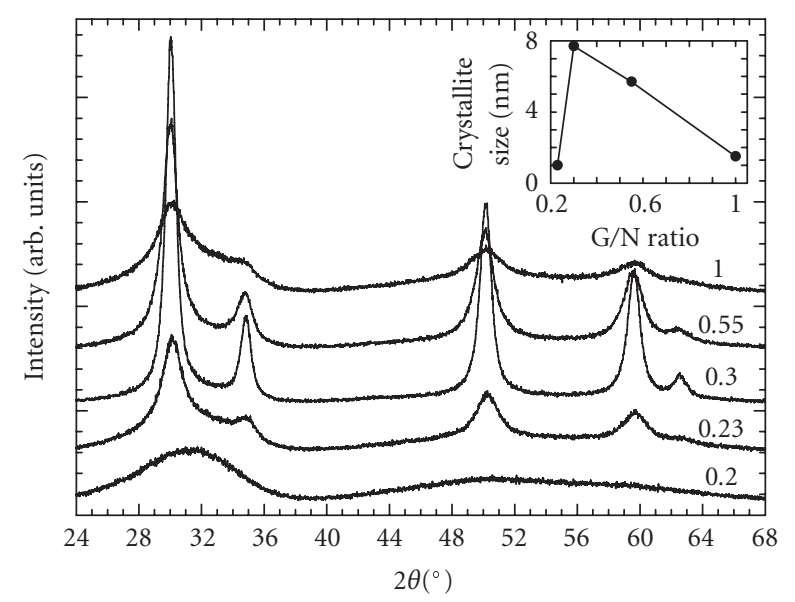

(a)

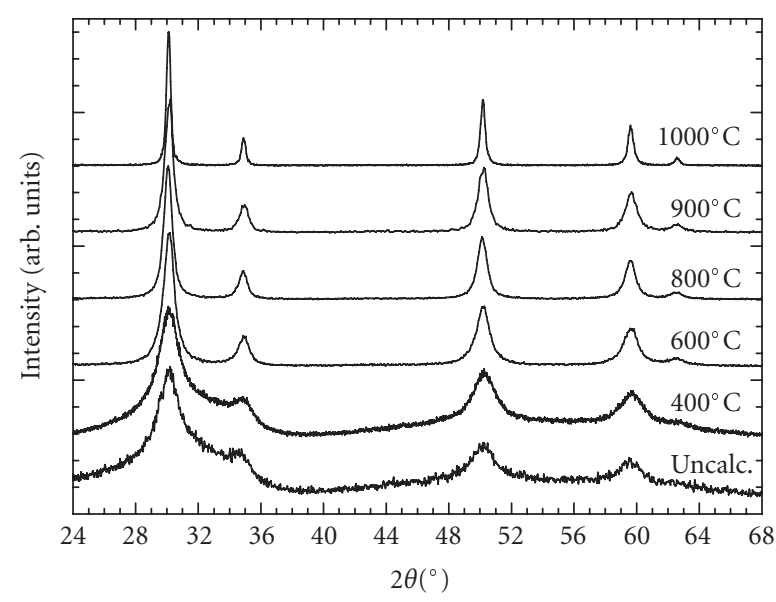

(b)

FIGURE 2: XRD diffractograms of (a) YSZ powders prepared using different $\mathrm{G} / \mathrm{N}$ ratios calcined at $400^{\circ} \mathrm{C}$ and (b) YSZ powders with $\mathrm{G} / \mathrm{N}=0.23$ calcined for $12 \mathrm{~h}$ at different temperatures. Insert shows crystallite size as a function of $\mathrm{G} / \mathrm{N}$ ratio.

At $1000^{\circ} \mathrm{C}$, however, the powder with $\mathrm{G} / \mathrm{N}=1.0$ has a crystallite size about twice that of the powder prepared with $\mathrm{G} / \mathrm{N}=0.23(\sim 30 \mathrm{~nm}$ and $\sim 15 \mathrm{~nm}$, resp. $)$.

The particle sizes for powders with $\mathrm{G} / \mathrm{N}=0.23$ calculated from the nitrogen adsorption data, are included in Figure 3 . The particle size is consistently larger than the crystallite size, showing that the powder is agglomerated and necks are formed between the particles. The temperature dependence is similar to that of the crystallite size, with a slow increase at low temperature and a rapid increase at higher temperatures. It should be noted, however, that the difference between crystallite size and particle size increases with increasing calcination temperature, indicating that the degree of agglomeration increases.

TEM micrographs of the powders with $\mathrm{G} / \mathrm{N}=0.30$, uncalcined, and 1.0 , calcined at $500^{\circ} \mathrm{C}$ are given in Figure 4 . The powder with $\mathrm{G} / \mathrm{N}=0.30$ (Figure $4(\mathrm{a})$ ) exhibits a crystallite size in the order of 10-15 nm. The insert in Figure 2(a) 


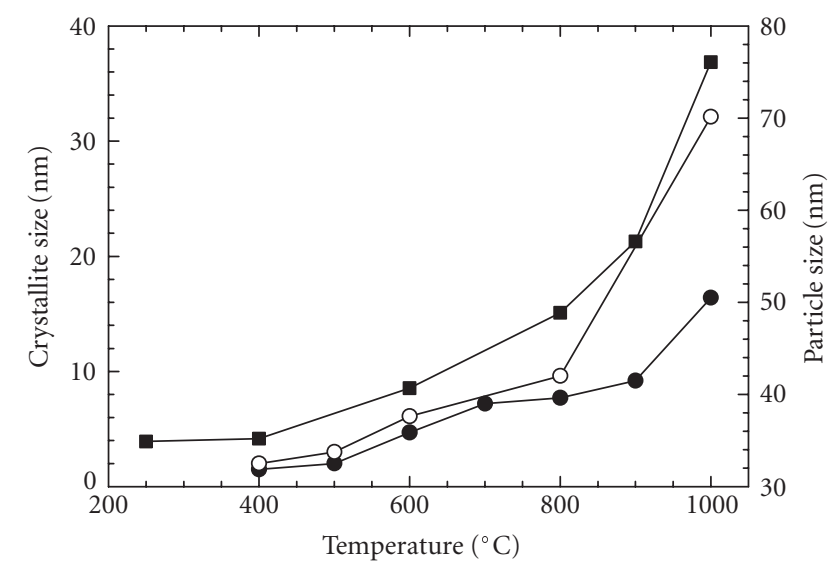

- Crystallite size, $\mathrm{G} / \mathrm{N}=0.23$

- Crystallite size, $\mathrm{G} / \mathrm{N}=1$

- Particle size, $\mathrm{G} / \mathrm{N}=0.23$

FIgURE 3: Crystallite size and particle size (calculated from BET measurements) of powders with $\mathrm{G} / \mathrm{N}=0.23$ and 1.0 , as a function of calcination temperature. Calcination time is $12 \mathrm{~h}$.

indicates that this $\mathrm{G} / \mathrm{N}$ ratio produces the largest crystallite size. The powder is mostly crystalline, and very little amorphous phase can be identified. The high $\mathrm{G} / \mathrm{N}$ ratio powder (Figure 4(b)) has crystallite size in the order of $5 \mathrm{~nm}$. There is, however, a large amount of amorphous phase between the crystallites.

The IR spectra of the powders with different G/N ratios calcined at $400^{\circ} \mathrm{C}$ are shown in Figure 5(a). The stretching frequency of $\mathrm{Zr}(\mathrm{Y})-\mathrm{O}$ is observed as the broad feature at about $500 \mathrm{~cm}^{-1}$, but in addition there are other spectral features with significant intensity. An overview of these is given in Table 1. The bands in the frequency region from 1200 to $1700 \mathrm{~cm}^{-1}$ are assigned to carbonate species formed by side-on coordination of $\mathrm{CO}_{2}$ molecules onto the coordinatively unsaturated $\mathrm{ZrO}_{2}$ surface [19]. The broad features at $\sim 1350$ and $1560 \mathrm{~cm}^{-1}$ are probably due to bidentate carbonate species [18]. Figure 5(a) shows that there are significant amounts of carbonate species remaining from the synthesis in all the powders calcined at $400^{\circ} \mathrm{C}$ independent of $\mathrm{G} / \mathrm{N}$ ratio. The strong sharp band at $1384 \mathrm{~cm}^{-1}$ might be due to physically side-on surface adsorbed $\mathrm{CO}_{2}$, as indicated by the sharpness of the band [14]. Also, it cannot be excluded that the powder with fuel deficiency contains traces of nitrates giving contributions to the broad absorption at around $1400 \mathrm{~cm}^{-1}$ [20]. The band observed at $\sim 2200 \mathrm{~cm}^{-1}$ for the samples with the largest fuel excess is attributed to adsorption of $\mathrm{CO}$ on the surface. The CO could stem from reducing conditions during the reaction of the fuel excess systems. The band at $2340 \mathrm{~cm}^{-1}$ is due to very labile linearly end-on coordinated $\mathrm{CO}_{2}$ [19]. The amount of physiosorbed $\mathrm{CO}_{2}$ is decreasing with increasing amount of fuel in the reaction mixture. The broad feature in the $3000-3600 \mathrm{~cm}^{-1}$ region is attributed to $\mathrm{O}-\mathrm{H}$ stretching of physiosorbed water or from surface-adsorbed hydroxyl groups.

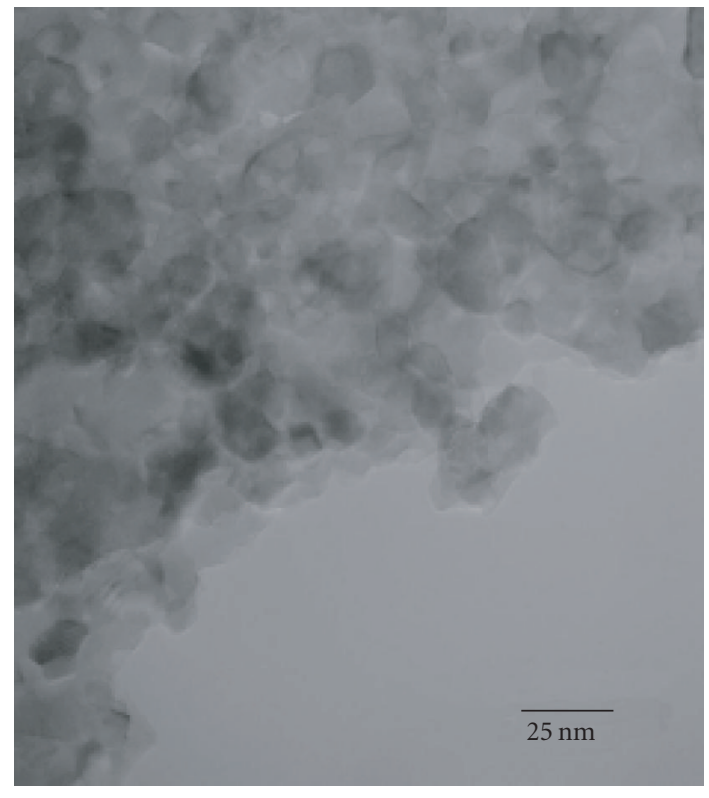

(a)

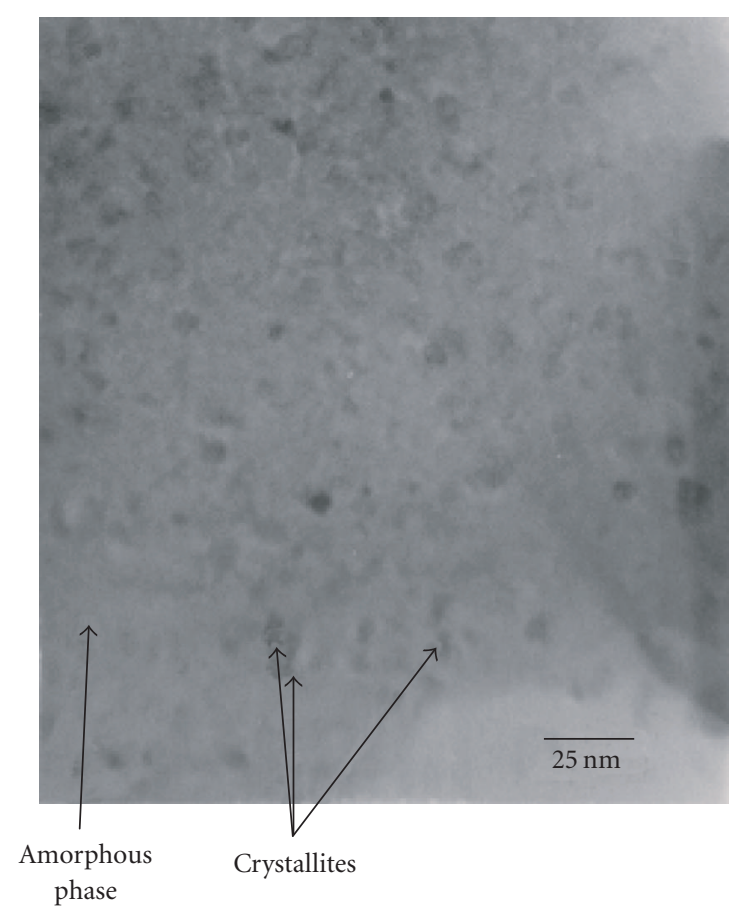

(b)

Figure 4: TEM micrographs of (a) powder with $\mathrm{G} / \mathrm{N}=0.30$, uncalcined, and (b) powder with $\mathrm{G} / \mathrm{N}=1$, calcined at $500^{\circ} \mathrm{C}$.

The IR spectra of powders with $\mathrm{G} / \mathrm{N}$ ratio of 0.23 as a function of calcination temperature are displayed in Figure 5(b). After calcination at $400^{\circ} \mathrm{C}$ a large amount of carbonate species are present in the powder as can be seen from the absorption in the spectral region from 1200 to $1700 \mathrm{~cm}^{-1}$. The amount of these carbonate species is decreasing with 


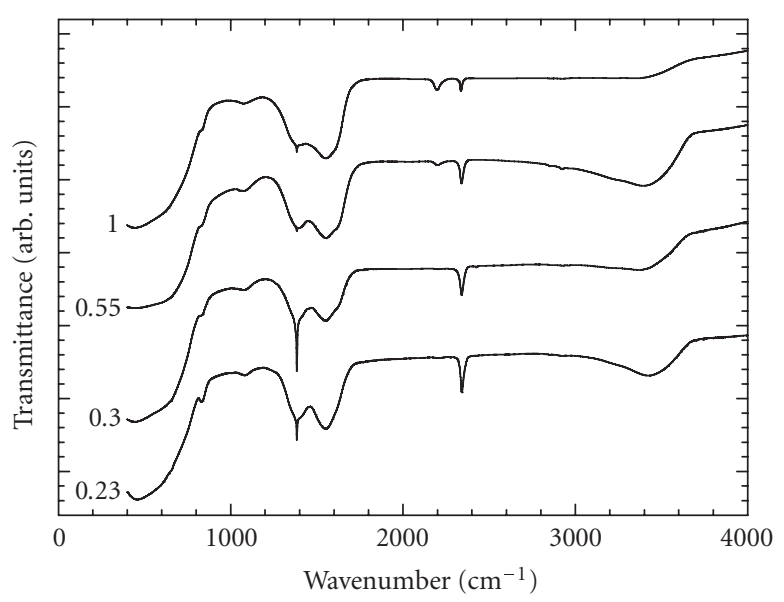

(a)

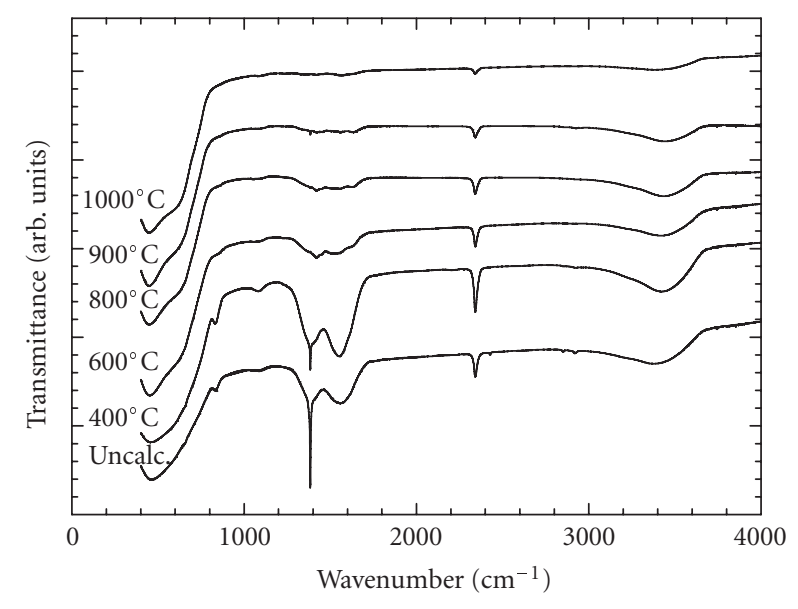

(b)

FIGURE 5: IR spectra of (a) YSZ powders produced with varying $\mathrm{G} / \mathrm{N}$ ratio and (b) powders with $\mathrm{G} / \mathrm{N}=0.23$ calcined for $0.5 \mathrm{~h}$ at various temperatures.

TABLE 1: Characteristic IR absorption bands.

\begin{tabular}{lcc}
\hline Frequency $\left(\mathrm{cm}^{-1}\right)$ & Assignation & Reference \\
\hline$\sim 500$ & $\mathrm{Zr}(\mathrm{Y})-\mathrm{O}$ stretching & {$[20]$} \\
1384 & Physically adsorbed $\mathrm{CO}_{2}$ & {$[14]$} \\
$\sim 1330$ and $\sim 1620$ & Bidentate carbonate species & {$[19]$} \\
2200 & Physically adsorbed CO & \\
2340 & Linearly coordinated surface $\mathrm{CO}_{2}$ & {$[19]$} \\
$3000-3600$ & $\mathrm{O}-\mathrm{H}$ stretching & {$[20]$} \\
\hline
\end{tabular}

increasing calcination temperature and above $900^{\circ} \mathrm{C}$ the material is virtually carbonate-free.

The TG data for powders with $\mathrm{G} / \mathrm{N}=0.23$ and 1.0 are shown in Figure 6. Two different sets with calcination temperatures of 400 and $650^{\circ} \mathrm{C}$, respectively, are shown. The powder with $\mathrm{G} / \mathrm{N}=1.0$, calcined at $400^{\circ} \mathrm{C}$ shows the greatest weight loss. In both samples there is a large weight loss

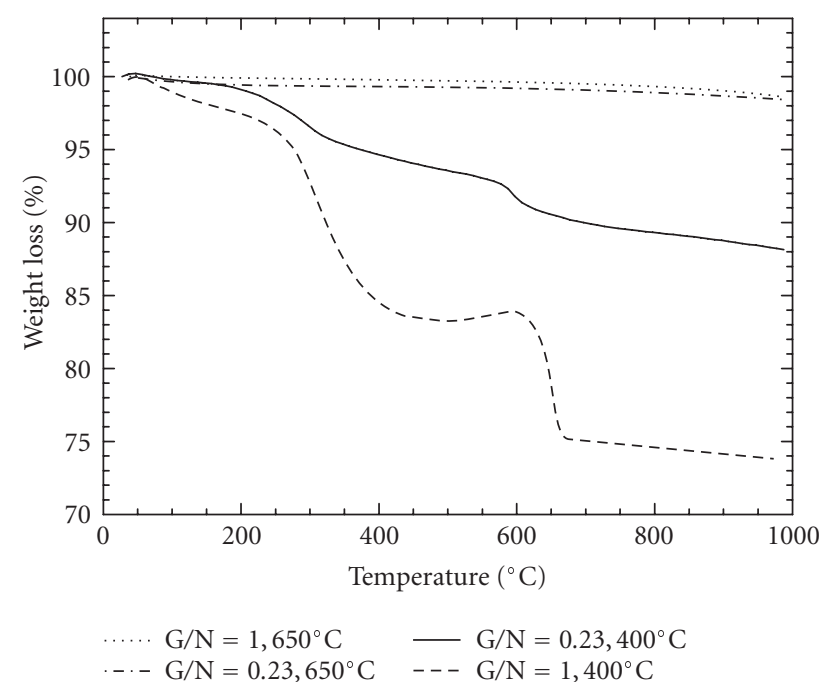

FIgure 6: Thermogravimetric data for powders with $\mathrm{G} / \mathrm{N}=0.23$ and 1.0 calcined at 400 and $650^{\circ} \mathrm{C}$.

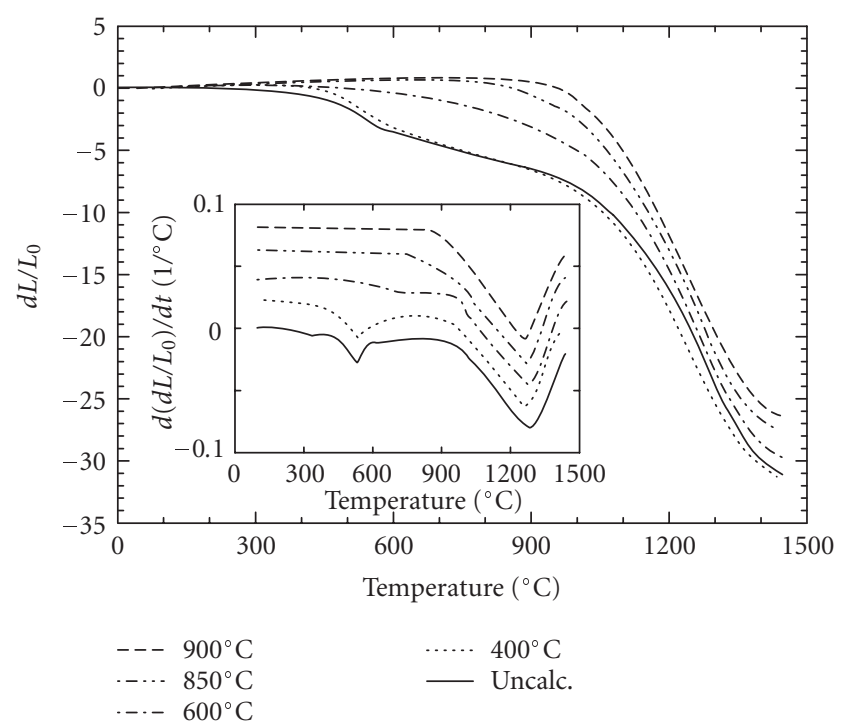

Figure 7: Dilatometer curves for samples with $\mathrm{G} / \mathrm{N}=0.23$, calcined at different temperatures. Insert shows the first derivative of the sintering. These curves are shifted relative to each other for easier viewing.

at $\sim 300^{\circ} \mathrm{C}$, and another, somewhat smaller, at $\sim 650^{\circ} \mathrm{C}$. After calcination at $650^{\circ} \mathrm{C}$, only limited weight loss is discernible in either of the samples.

The sintering curves for powder compacts with a $\mathrm{G} / \mathrm{N}$ ratio of 0.23 with varying calcination temperature are shown in Figure 7, and the derivatives of the curves are shown in the insert. Densities of the heat-treated samples calcined below $600^{\circ} \mathrm{C}$ were $95.5 \%$ of theoretical, whereas the samples calcined at higher temperatures obtained densities of $97 \%$ of theoretical. The sintering curves of the powders with low 
calcination temperature exhibit a shrinkage step at $\sim 500$ $600^{\circ} \mathrm{C}$. From the insert in Figure 7, this first step is obvious for the two samples with the lowest calcination temperature, but the pre-sintering step is observed for all the samples. The magnitude of the step decreases with increasing calcination temperature, whereas the onset temperature increases and is always above the calcination temperature.

\section{DISCUSSION}

\subsection{Synthesis}

For YSZ where no catalytic active cations are present, the combustion reaction was observed to be in the smoldering combustion mode for all the $\mathrm{G} / \mathrm{N}$-ratios studied. In addition to the type of cations, the G/N-ratio will influence the temperature of the given combustion reaction. The temperature determines the degree of completion of the combustion reaction, and hence the amount of residual carbonaceous species in the powder. According to Chick et al. [12], the best powder quality is achieved when the combustion temperature is the highest. If the crystallite size is a direct indication of the combustion temperature, the maximum crystallite size (Figure 2), and hence combustion temperature, occurred for a $\mathrm{G} / \mathrm{N}$ ratio of 0.30 . This is not consistent with the observations of Chick et al. [12] for other materials. As we observed a decrease in crystallite size above $\mathrm{G} / \mathrm{N}=0.30$, this could indicate a decrease in combustion temperature. However, the TEM micrographs (Figure 4) show that the powder with a $\mathrm{G} / \mathrm{N}$ ratio of 1.0 contains a fair amount of amorphous matrix phase, and it is also seen from the IR data (Figure 5(a)) that this sample contains a large amount of residual carbonate species. A possible explanation for the decrease in crystallite size, in addition to or instead of a decreasing combustion temperature, could be that the residual carbonate species reside in the amorphous matrix, inhibiting crystallization of cubic YSZ. A higher calcination temperature is then required for the crystallization of materials containing carbonate species.

The $\mathrm{G} / \mathrm{N}$ ratio of $0.23(\mathrm{G} / \mathrm{C}=0.50)$ corresponds to the exact composition where both ends of every glycine molecule are complexed with either a $\mathrm{ZrO}^{2+}$ ion or a $\mathrm{Y}^{3+}$ ion. No precipitation was observed, indicating that the $\mathrm{ZrO}^{2+}$ ion can indeed use both ends of the glycine molecule for complexation (Figure 1). There is also no indication of precipitation in the XRD data, as all powders appear to be single-phase cubic zirconia, with a consistent unit cell parameter. If precipitation had occurred, this could have caused appearance of peaks of monoclinic/tetragonal $\mathrm{ZrO}_{2}$ in the X-ray diffractograms, and also a shift in the YSZ lattice parameter as the $\mathrm{Y}: \mathrm{Zr}$ ratio changed. Even for $\mathrm{G} / \mathrm{N}$ below 0.23 no precipitation was observed.

\subsection{Calcination}

Calcination of the powder was performed under oxygen flow, due to the necessity of removing residual carbonate species. Ideally, the calcination temperature should be as low as possible in order to avoid crystallite growth. As illustrated for powders with $\mathrm{G} / \mathrm{N}=0.23$ in Figure 5(b), the amount of residual carbonate residue decreases with increasing calcination temperature, and at $800^{\circ} \mathrm{C}$ most of the carbonate residue has been removed. This correlates well with the TG data (Figure 6), which show no significant weight loss after calcination at $650^{\circ} \mathrm{C}$.

The powders with $\mathrm{G} / \mathrm{N}=0.23$ exhibit much less crystallite growth than the $\mathrm{G} / \mathrm{N}=1.0$ powder in the hightemperature regime, and the crystallite sizes at $1000^{\circ} \mathrm{C}$ are approximately $15 \mathrm{~nm}$ and $30 \mathrm{~nm}$, respectively. The two powders are, however, quite comparable at low temperatures, though the degree of crystallization is different due to the presence of residual carbonate materials in the powder with $\mathrm{G} / \mathrm{N}=1.0$ (Figure 6). The high-temperature behavior is important for further sintering studies, which must necessarily take place at an elevated temperature.

\subsection{Sintering}

The sinterability of the powder was affected by the presence of residual carbonate species in the matrix. The presintering step that is observed for low calcination temperatures is most likely due to the main removal of residual carbonate species, and the temperature at which this step occurs correlates reasonably well with the step in the TG curve (Figure 6). At higher calcination temperatures, where, according to the TG data, most carbonate species have been removed, there is also a hint of a presintering step (Figure 7 insert). This effect may be due to the final removal of carbonate species, as there is an indication in the IR data (Figure 5(b)) that there are still small amounts left even above $650^{\circ} \mathrm{C}$.

The sintering curves also indicate that the sintering onset occurs at a slightly lower temperature when the calcination temperature is increased. This is also most likely due to the necessity of removing residual carbonate species prior to onset of the main sintering step, which is then delayed in carbonate-rich samples.

According to conventional sintering theory, the sinterability increases with decreasing crystallite size [21]. In these powders, this effect is overshadowed by the lower sinterability due to the presence of carbonate species. These two effects would counteract each other, as the samples with smaller crystallite size also contain more carbonate. The effect of crystallite size on the sinterability of these powders can hence not be determined. Theoretically, the ideal powder for sintering would have the smallest crystallites possible, and, in this case, the smallest amount of carbonate. In order to achieve this, it is advantageous to start with the uncalcined powder with the least carbonate, that is, in the lower G/N range. XRD data indicate that the $\mathrm{G} / \mathrm{N}$ ratio should be at least 0.23 , as below this the powder is amorphous.

The final density of the samples calcined at $600^{\circ} \mathrm{C}$ and above, where most of the residual carbonate matter has been removed, was about $1.5 \%$ higher than those calcined below $600^{\circ} \mathrm{C}$. This confirms that the sinterability of the powder is indeed affected by the presence of residual carbonate compounds, and that it is important to limit their presence. 
The effects of the residual carbonates may seem small, both with regards to the changes in sintering onset and final density, but it should be taken into account that the trends should have been reversed, if the only observed effect had been that of the crystallite size. The effect is hence larger than we observe.

\section{CONCLUSION}

Nanocrystalline YSZ powders with 8 mol\% $\mathrm{Y}_{2} \mathrm{O}_{3}$ have been synthesized by the smoldering combustion synthesis. The powder with the best characteristics with regards to sinterability was found to be that with the least amount of residual carbonate species, that is, the one with a $\mathrm{G} / \mathrm{N}$ ratio of 0.23 . Calcination at $650^{\circ} \mathrm{C}$ or above produced the densest sintered bodies as calcination at this temperature removed most remnants of carbonate species.

\section{ACKNOWLEDGMENTS}

The authors thank the Norwegian University for Science and Technology for the funding for this project. Dr. Yingda Yu is acknowledged for help with the TEM.

\section{REFERENCES}

[1] N. Q. Minh and T. Takahashi, Science and Technology of Ceramic Fuel Cells, Elsevier Science B. V., Amsterdam, The Netherlands, 1995.

[2] S. K. Tadokoro and E. N. S. Muccillo, "Physical characteristics and sintering behavior of ultrafine zirconiaceria powders," Journal of the European Ceramic Society, vol. 22, no. 9-10, pp. 1723-1728, 2002.

[3] S.-G. Chen, Y.-S. Yin, D.-P. Wang, and J. Li, "Reduced activation energy and crystalline size for yttria-stabilized zirconia nano-crystals," Journal of Crystal Growth, vol. 267, no. 1-2, pp. 100-109, 2004.

[4] S. Jiang, W. A. Schulze, V. R. W. Amarakoon, and G. C. Stangle, "Electrical properties of ultrafine-grained yttria-stabilized zirconia ceramics," Journal of Materials Research, vol. 12, no. 9, pp. 2374-2380, 1997.

[5] Y. Wu, A. Bandyopadhyay, and S. Bose, "Processing of alumina and zirconia nano-powders and compacts," Materials Science and Engineering A, vol. 380, no. 1-2, pp. 349-355, 2004.

[6] K. C. Patil, S. T. Aruna, and T. Mimani, "Combustion synthesis: an update," Current Opinion in Solid State \& Materials Science, vol. 6, no. 6, pp. 507-512, 2002.

[7] C. Laberty-Robert, F. Ansart, C. Deloget, M. Gaudon, and A. Rousset, "Powder synthesis of nanocrystalline $\mathrm{ZrO}_{2}-$ $8 \% \mathrm{Y}_{2} \mathrm{O}_{3}$ via a polymerization route," Materials Research Bulletin, vol. 36, no. 12, pp. 2083-2101, 2001.

[8] C. Laberty-Robert, F. Ansart, C. Deloget, M. Gaudon, and A. Rousset, "Dense yttria stabilized zirconia: sintering and microstructure," Ceramics International, vol. 29, no. 2, pp. 151$158,2003$.

[9] Y. B. Khollam, A. S. Deshpande, A. J. Patil, H. S. Potdar, S. B. Deshpande, and S. K. Date, "Synthesis of yttria stabilized cubic zirconia (YSZ) powders by microwave-hydrothermal route," Materials Chemistry and Physics, vol. 71, no. 3, pp. 235-241, 2001.
[10] T. Mimani and K. C. Patil, "Solution combustion synthesis of nanoscale oxides and their composites," Materials Physics and Mechanics, vol. 4, no. 2, pp. 134-137, 2001.

[11] J. Kragten, Atlas of Metal-Ligand Equilibria in Aqueous Solution, Ellis Horwood, Chichester, UK, 1978.

[12] L. A. Chick, L. R. Pederson, G. D. Maupin, J. L. Bates, L. E. Thomas, and G. J. Exarhos, "Glycine-nitrate combustion synthesis of oxide ceramic powders," Materials Letters, vol. 10, no. 1-2, pp. 6-12, 1990.

[13] A. S. Mukasyan, C. Costello, K. P. Sherlock, D. Lafarga, and A. Varma, "Perovskite membranes by aqueous combustion synthesis: synthesis and properties," Separation and Purification Technology, vol. 25, no. 1-3, pp. 117-126, 2001.

[14] T. Mokkelbost, I. Kaus, T. Grande, and M.-A. Einarsrud, "Combustion synthesis and characterization of nanocrystalline $\mathrm{CeO}_{2}$-based powders," Chemistry of Materials, vol. 16, no. 25, pp. 5489-5494, 2004.

[15] PROFILE PLUS, v. 1.07, DIFFRAC Plus Package, BRUKER AXS GmbH, 1996.

[16] WIN-CRYSIZE, v. 3.04, SIGMA-C GmbH 1991-1997.

[17] http://ts.nist.gov/ts/htdocs/230/232/232.htm.

[18] A. J. Feighery and J. T. Irvine, "Effect of alumina additions upon electrical properties of $8 \mathrm{~mol}$ \% yttria-stabilised zirconia," Solid State Ionics, vol. 121, no. 1-4, pp. 209-216, 1999.

[19] V. Bolis, G. Magnacca, G. Cerrato, and C. Morterra, "Microcalorimetric and IR-spectroscopic study of the room temperature adsorption of $\mathrm{CO}_{2}$ on pure and sulphated $\mathrm{t}-\mathrm{ZrO} 2$," Thermochimica Acta, vol. 379, no. 1-2, pp. 147-161, 2001.

[20] K. Nakamoto, Infrared and Raman Spectra of Inorganic and Coordination Compounds, John Wiley \& Sons, New York, NY, USA, 2nd edition, 1997.

[21] R. M. German, Sintering Theory and Practice, John Wiley \& Sons, New York, NY, USA, 1996. 

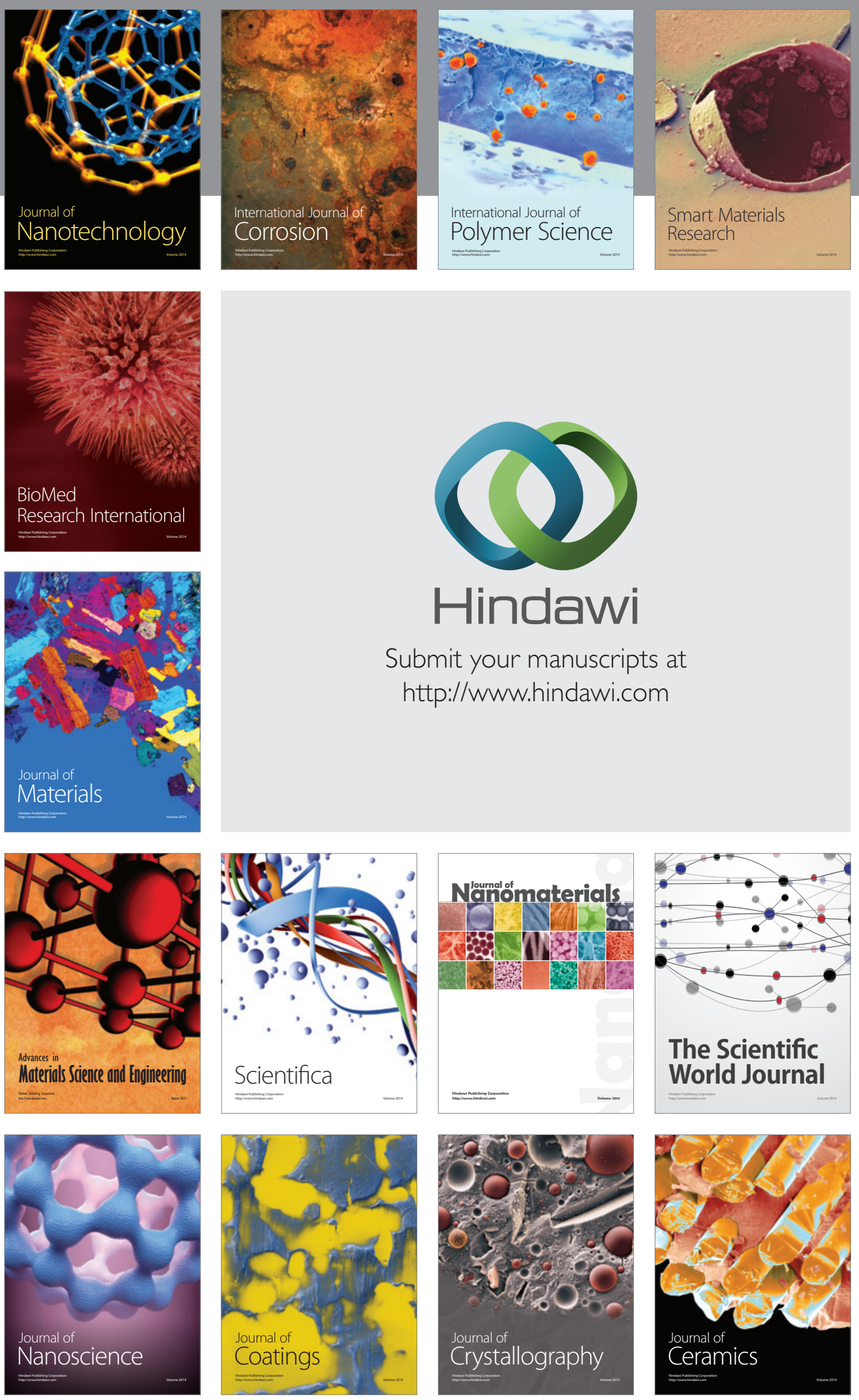

The Scientific World Journal

Submit your manuscripts at

http://www.hindawi.com

\section{World Journal}

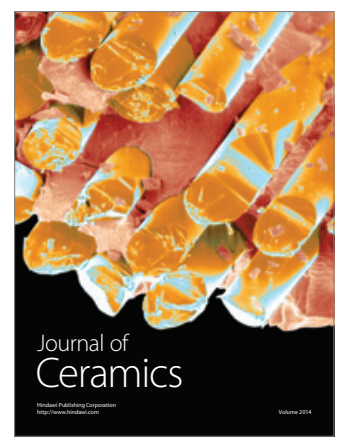

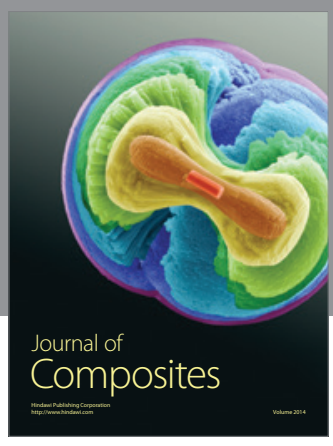
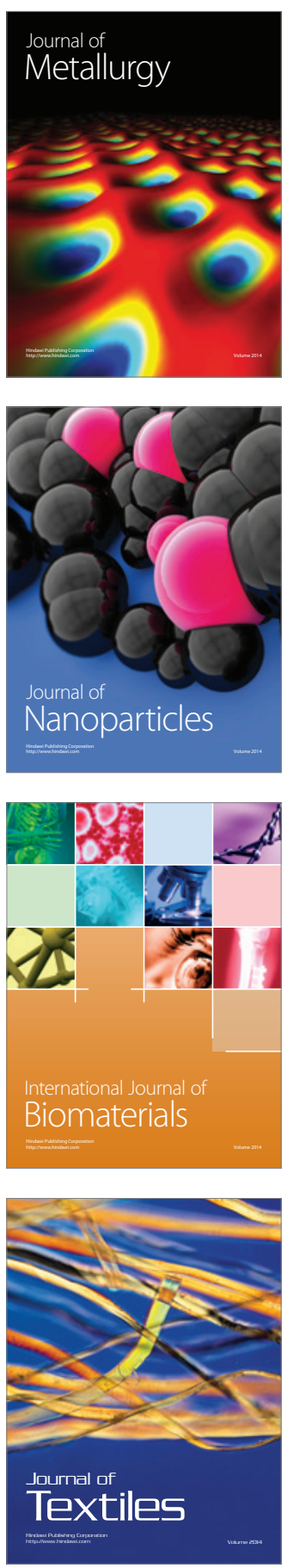